\title{
HAZOP JAKO METODA WSPOMAGAJĄCA ZARZĄDZANIE BEZPIECZEŃSTWEM PROCESOWYM W PRZEDSIĘBIORSTWIE
}

Z a r y s t r e ś c i: Artykuł stanowi próbę ukazania roli metody HAZOP w zarządzaniu bezpieczeństwem procesowym w przedsiębiorstwie. Metoda HAZOP jest analizą zagrożeń i zdolności operacyjnych wykorzystywanych do oceny ryzyka procesowego opisaną szczegółowo w normie IEC 61882 „Hazard and operability studies (HAZOP studies) - Application guide”, wydanej w 2001 r. Celem analizy HAZOP jest zidentyfikowanie wszystkich potencjalnych zagrożeń i strat, jakie mogą wystąpić w realizowanych działaniach. Ma to duże znaczenie w zarządzaniu bezpieczeństwem procesowym szczególnie w branży chemicznej, petrochemicznej. gazowej i energetycznej.

S ł o w a k 1 u c z o w e: zarządzanie; zarządzanie procesami; zarządzanie ryzykiem operacyjnym.

Klasyfikacja JEL: D24.

Tam, gdzie wzmaga się zagrożenie, tam rośnie $w$ siłe to, co przed nim ratuje

Friedrich Hölderlin

* Adres do korespondencji: Leszek Pruszkowski, Szkoła Wyższa im. Pawła Włodkowica w Płocku, Wydział Zarządzania, al. Kilińskiego 12, Płock, e-mail: pruszkowski.leszek@gmail.com 


\section{WSTĘP}

Współczesna gospodarka opiera się na wykorzystywaniu bardzo wielu różnorodnych technologii, które wykształciły specyficzne środowisko pracy. Obserwujemy nieodwracalny progres cywilizacyjny i technologiczny napędzany nieustannym dążeniem do innowacyjności. Konsekwencją tak dużego postępu gospodarczego jest ujawnienie się dużej liczby różnego rodzaju ryzyk i zagrożeń wywołanych działalnością człowieka. Ich powszechność i uspołecznienie oraz możliwość transformacji (ryzyko technologiczne może się przekształcić w ryzyko finansowe, ryzyko naturalne w ryzyko technologiczne itd.) powoduje, że współczesne społeczeństwo, jak nigdy wcześniej, jest narażone na ryzyko. Odpowiedzią na powstałą sytuację są różnego rodzaju działania obronne. W latach siedemdziesiątych XX wieku wyodrębniła się nowa dziedzina wiedzy, którą nazwano bezpieczeństwem procesowym.

\section{ZARZĄDZANIE BEZPIECZEŃSTWEM PROCESOWYM W PRZEDSIĘBIORSTWIE}

Bezpieczeństwo procesowe, rozumiane jako brak niemożliwego do zaakceptowania ryzyka dla zdrowia, życia lub strat w majątku czy środowisku naturalnym, ma szczególne znaczenie w przemyśle chemicznym, petrochemicznym, w gazownictwie i energetyce. Jest integralną częścią ogólnego bezpieczeństwa, szczególnie odnosi się do instalacji procesowych zawierających i przerabiających substancje chemiczne. Bezpieczeństwo procesu produkcyjnego obejmuje zarówno bezpieczeństwo pracowników, jak i procesów technologicznych. Wiąże się to z takim zaprojektowaniem i wykonaniem technologicznych instalacji przemysłowych, które uwzględnia warunki zapewnienia ich bezpiecznego działania. Dotyczy to zwłaszcza procesów przemysłowych, podczas których zachodzące reakcje chemiczne lub zmiany stanu skupienia substancji powodują zagrożenia dla ludzkiego zdrowia, a nawet życia oraz środowiska [Gruhn, Chedde, 2006, s. 57]. Przedsiębiorstwa, w ramach kompleksowego zapewnienia bezpieczeństwa, wdrażają systemy zarządzania bezpieczeństwem procesowym. Przy opracowywaniu takich systemów uwzględnia się zasady bezpieczeństwa procesowego stanowiące wytyczne do projektowania i wykonywania wszelkich działań produkcyjnych, a dotyczące bezpieczeństwa naturalnego, opartego 
na filozofii eliminacji zagrożeń, zmniejszenie ich potencjalnych skutków poprzez zastępowanie niebezpiecznych substancji, zmniejszanie ilości stosowanych substancji oraz, o ile to możliwe, obniżanie parametrów operacyjnych procesów. Powszechnie wykorzystuje się wielowarstwowość systemów bezpieczeństwa i ochrony, którą tworzą niezależne, szeregowo działające systemy zabezpieczeń w postaci warstwy zapobiegania uwolnieniom substancji niebezpiecznych, warstwy ochrony przed skutkami takich uwolnień i warstwy przeciwdziałania, minimalizującej wielkość strat wskutek tych uwolnień [Kunicki, Matus, Zabielski, 2001, s. 23]. Kluczową kwestią w zarządzaniu bezpieczeństwem procesowym są analizy oceny ryzyka, identyfikujące zagrożenia związane z procesami i umożliwiające odpowiedni dobór systemów bezpieczeństwa.

\section{GENEZA I IDEA METODY HAZOP}

Metoda HAZOP (Hazard and Operability Study) została zapoczątkowana w Anglii w 1963 r. w koncernie Imperial Chemical Industries (ICI), jednym z największych producentów artykułów chemicznych na świecie. Upubliczniona została przez ICI oraz Chemical Industries Assocciations Ltd. w 1977 r. W 2001 r. ukazała się norma IEC 61882 „Hazard and operability studies (HAZOP studies) - Application guide". W czerwcu 2005 r. opublikowana została polska wersja tej normy, została ona przetłumaczona przez Polski Komitet Normalizacyjny i ma ten sam status co wersja oficjalna. Celem normy jest przedstawienie zasad i procedur badań zagrożeń i zdolności do działania. HAZOP jest ustrukturyzowaną i systematyczną techniką badania określonego systemu w celu identyfikowania potencjalnych zagrożeń w systemie oraz potencjalnych problemów związanych ze zdolnością do działania systemu i w szczególności identyfikowania przyczyn zakłóceń działania i powstawania odchyleń w produkcji, które mogą doprowadzić do powstania wyrobów niezgodnych. Metoda HAZOP jest analizą zagrożeń i zdolności operacyjnych wykorzystywanych do oceny ryzyka procesowego. Celem analizy HAZOP jest zidentyfikowanie wszystkich potencjalnych zagrożeń i strat, jakie mogą wystąpić w przedsięwzięciach. Analiza zagrożeń i zdolności operacyjnych jest strukturalną metodą identyfikacji potencjalnych zagrożeń występujących w procesach przemysłowych [Kletz, 1999, s. 27]. W praktyce oznacza to systematyczny przegląd założeń projektowych i procesu technologicznego pod kątem mogących pojawić się odchyleń parametrów. 
Cechą charakterystyczną badania HAZOP jest „sesja badawcza”, podczas której interdyscyplinarny zespół pod przewodnictwem kierownika dokonuje systematycznego badania wszystkich istotnych elementów systemu lub projektu. Zespół w toku pracy identyfikuje i ujawnia wszelkie odchylenia od założeń projektu. Wykorzystuje do tego tzw. „słowa kluczowe”. Słowa kluczowe są techniką, która służy do stymulacji wyobraźni członów zespołu w celu skuteczniejszego identyfikowania zagrożeń i problemów i zdolności do działania.

\section{ZASADY HAZOP}

Należy podkreślić, że badanie HAZOP jest procesem twórczym. Analiza jest prowadzona poprzez systematyczne stosowanie serii słów kluczowych, aby skutecznie identyfikować potencjalne odchylenia od założeń projektu. Odchylenia są stosowane jako ,mechanizmy wyzwalające” w celu inspirowania członków zespołu do oceny, jakie były przyczyny powstałego odchylenia i jakie mogą być jego skutki. Badanie powinno być prowadzone pod kierunkiem przeszkolonego i doświadczonego kierownika, którego rolą jest zapewnienie wszechstronnego ujęcia badanego systemu przy zastosowaniu logicznego i analitycznego myślenia. Kierownikowi powinien towarzyszyć sekretarz, który zapisuje zidentyfikowane zagrożenia i/lub zakłócenia zdolności do działania w celu dalszej oceny i wypracowania decyzji. Badanie prowadzone jest $\mathrm{z}$ udziałem specjalistów reprezentujących różne dyscypliny, posiadających odpowiednie umiejętności i doświadczenie oraz charakteryzujących się intuicją i predyspozycjami do właściwego osądu. Zalecane jest, by prowadzić badania w atmosferze pozytywnego myślenia i szczerej dyskusji. Zidentyfikowane problemy są zapisywane w celu oceny i w konsekwencji podjęcia decyzji.

Dla ułatwienia badania system zostaje podzielony na części, dla których założenia projektowe mogłyby być właściwie ustalone. Rozmiar wybranej części zależy zwykle od stopnia złożoności systemu i dotkliwości zagrożenia. Dla złożonych systemów lub dla systemów, które są narażone na duże zagrożenia wyodrębnione części są raczej małe. Z kolei dla systemów prostych lub dla systemów narażonych na małe zagrożenia wyodrębnia się większe części, co w istotny sposób przyspiesza badanie [Borysiewicz, Furtek, Potempski, 2000, s. 58]. W przemyśle chemicznym w celu przeprowadzenia analizy HAZOP należy instalacje produkcyjne podzielić na tzw. węzły badawcze (jednostki procesowe lub operacje jednostkowe 
posiadające określone funkcje). Każdy węzeł badawczy stanowi kolejny krok analizy.

Tabela 1. Idea wyodrębniania części badawczych w analizie HAZOP

\begin{tabular}{|c|c|c|c|}
\hline \multicolumn{4}{|c|}{ Instalacja } \\
\hline Węzeł 1 (krok 1) & Węzeł 2 (krok 2) & Węzeł 3 (krok 3) & Węzeł 4 (krok 4) \\
\hline $\begin{array}{c}\text { Np. rurociąg } \\
\text { magistralny }\end{array}$ & $\begin{array}{c}\text { Np. zbiornik } \\
\text { magazynowy }\end{array}$ & Np. pompa & Np. piec \\
\hline \multicolumn{4}{|c|}{} \\
& $\leftarrow$ FUNKCJONALNA CAt OŚć $\longrightarrow$ \\
\hline
\end{tabular}

Źródło: opracowanie własne na podstawie autentycznych analiz HAZOP.

Dla danej części systemu założenia projektu są wyrażane za pomocą elementów, które przekazują podstawowe jej cechy. Wybór elementów do badania jest do pewnego stopnia subiektywny i w praktyce może być wiele możliwości przeprowadzenia badania. Najczęściej kryterium wyodrębnienia części może być materiał wejściowy uzyskany ze źródła, działanie, które jest podejmowane na danym materiale albo wyrób, który jest dostarczony na miejsce przeznaczenia. Elementy mogą być określane użytecznie ze względu na kryteria ilościowe, jakościowe lub właściwości. W systemie chemicznym element „materiał” może być definiowany dalej ze względu na cechy takie jak temperatura, ciśnienie, skład. Z kolei dla działania transport istotnymi właściwościami mogą być częstość kursowania lub liczba pasażerów.

Zespół HAZOP bada każdy element pod względem odchyleń od założeń projektu, które mogą prowadzić do niepożądanych skutków. Identyfikowanie odchyleń od założeń projektu jest osiągane dzięki procesowi pytań z zastosowaniem wcześniej określonych „słów kluczowych” [Redmill, Chudleigh, Catmur, 1999, s. 68].

Słowa kluczowe tworzone są przez połączenie słów przewodnich $\mathrm{z}$ odpowiednim parametrem procesowym. Połączenie odpowiedniego parametru ze słowem przewodnim pozwala na stworzenie słowa kluczowego, według którego prowadzona jest analiza HAZOP (np. brak przepływu, większy przepływ, mniejszy przepływ, przepływ odwrotny). 
Tabela 2. Słowa przewodnie do tworzenia słów kluczowych w analizie HAZOP

\begin{tabular}{|c|c|}
\hline Słowo przewodnie & Znaczenie \\
\hline Nie ma (brak) & Negacja intencji \\
\hline Więcej / mniej, większy / mniejszy & Ilościowy wzrost / obniżenie \\
\hline Lepszy / gorszy & Jakościowy wzrost / obniżenie \\
\hline odwrotny & Przeciwny do zamierzonego \\
\hline inny & Inny niż zamierzony \\
\hline Inny niż & Całkowite zastąpienie \\
\hline Wcześniej / później, przed / po & Zmiana w czasie \\
\hline Częściowo, także & Jakościowe obniżenie \\
\hline Również jak, w dodatku do & Jakościowo zwiększenie \\
\hline
\end{tabular}

Źródło: opracowanie własne na podstawie autentycznych analiz HAZOP.

Istotne jest, aby kolejno sięgać do poszczególnych parametrów i słów przewodnich i w ten sposób kontynuować analizę.

Tabela 3. Parametry do tworzenia słów kluczowych w analizie HAZOP

\begin{tabular}{|c|c|c|c|}
\hline Przepływ & Czas & Częstość & Mieszanie \\
\hline Ciśnienie & Skład & Lepkość & Dodawanie \\
\hline Temperatura & $\mathrm{pH}$ & Napięcie & Oddzielanie \\
\hline Poziom & Prędkość & Informacja & Reakcja \\
\hline Operacja & Opróżnianie & Utrzymanie & Korozja \\
\hline Tryb pracy & Położenie & Ładunek & $\begin{array}{c}\text { Medium pomoc- } \\
\text { nicze }\end{array}$ \\
\hline Zasilanie & $\begin{array}{c}\text { Warunki atmosfe- } \\
\text { ryczne }\end{array}$ & Stężenie & Gęstość \\
\hline Odpuszczanie & Integralność & Inny & Inny (ustala Zespół) \\
\hline
\end{tabular}

Źródło: opracowanie własne na podstawie autentycznych analiz HAZOP. 
Rolą słowa kluczowego jest pobudzanie twórczego myślenia, większa koncentracja na czynnikach zagrożeń i kreowanie pomysłów do dyskusji, a przez to zwiększenie szans na pełne zrealizowanie badania.

\section{PROCEDURA BADANIA HAZOP}

Procedura analizy HAZOP obejmuje cztery główne etapy, w ramach których realizowane są zadania szczegółowe:

- ustalenia,

- przygotowania,

- badanie,

- dokumentacja i dalsze badania [Kunicki, Matus, Zabielski, 2001, s. 25].

Pełen zakres działań szczegółowych realizowanych w ramach poszczególnych etapów zawiera tabela 4.

Rozpoczęcie badania zwykle jest inicjowane przez kierownika przedsięwzięcia. Ustala on termin badania, powołuje kierownika badania i zapewnia niezbędne zasoby do jego przeprowadzenia. Potrzeba badania HAZOP często bywa identyfikowana podczas rutynowego planowania przedsięwzięcia.

Określenie zakresu i celów badania przeprowadza kierownik przedsięwzięcia przy udziale kierownika badania. Cele i zakres badania są wzajemnie zależne i powinny być opracowane łącznie. Celem badania HAZOP jest zidentyfikowanie wszystkich potencjalnych zagrożeń i strat, jakie mogą wystąpić w przedsięwzięciu.

Zakres analizy HAZOP uwzględnia fizyczne granice systemu oraz liczbę i poziom szczegółowo dostępnego planu projektu. W przemyśle chemicznym zakres badania obejmuje podział instalacji produkcyjnych na węzły badawcze (jednostki procesowe lub operacje jednostkowe mające określone funkcje) podlegające analizie, następnie ustalenie tzw. głębokości analizy, czyli zakresu szczegółowości analizy i wreszcie czasu trwania analizy oraz dostępności środków. 
Tabela 4. Procedura badań HAZOP

\begin{tabular}{|c|c|}
\hline Etap badań & Zakres działań \\
\hline Ustalenia & $\begin{array}{l}\text { - Określenie zakresu i celów } \\
\text { - Określenie odpowiedzialności } \\
\text { - Wybranie zespołu }\end{array}$ \\
\hline Przygotowania & $\begin{array}{l}\text { - Sporządzenie planu badania } \\
\text { - Zebranie danych } \\
\text { - Uzgodnienie rodzajów zapisów } \\
\text { - Oszacowanie czasu } \\
\text { - Opracowanie harmonogramu }\end{array}$ \\
\hline Badanie & $\begin{array}{l}\text { - Podział systemu na części } \\
\text { - Wybór części i ustalenie założeń projektu } \\
\text { - Identyfikacja odchyleń dzięki użyciu słów kluczowych } \\
\text { wobec każdego elementu } \\
\text { - Identyfikacja skutków i przyczyn } \\
\text { - Identyfikacja istnienia znaczącego problemu } \\
\text { - Identyfikacja mechanizmów zabezpieczających } \\
\text { - Identyfikacja możliwych środków zaradczych } \\
\text { - Uzgodnienie działań }\end{array}$ \\
\hline $\begin{array}{c}\text { Dokumentacja i dalsze } \\
\text { badania }\end{array}$ & $\begin{array}{l}\text { - Zapisanie badań } \\
\text { - Podpisanie dokumentacji } \\
\text { - Opracowanie raportu z badań } \\
\text { - Sprawdzenie, czy działania są wdrożone } \\
\text { - Powtórne badania każdej części systemu } \\
\text { w razie konieczności } \\
\text { - Opracowanie raportu końcowego }\end{array}$ \\
\hline
\end{tabular}

Źródło: Opracowanie własne na podstawie PN-IEC 61882 Badania zagrożeń i zdolności do działania (badania HAZOP) - Przewodnik zastosowań.

Role i odpowiedzialność zespołu HAZOP powinny być jasno określone przez kierownika przedsięwzięcia i uzgodnione z kierownikiem badania HAZOP na początku badania. Badanie HAZOP jest pracą zespołową, w której każdy z członków zespołu zostaje przydzielony do określonej roli. Zaleca się, aby zespół był możliwie najmniejszy, w zgodzie z posiadanymi technicznymi i eksploatacyjnymi umiejętnościami i doświadczeniem.

Prace przygotowawcze $w$ dużej mierze spoczywają na kierowniku badania. Jest on odpowiedzialny za: 
- pozyskanie informacji,

- przekształcenie informacji w stosowny format,

- planowanie kolejności spotkań,

- organizowanie koniecznych spotkań.

Kierownik badania odpowiedzialny jest za przygotowanie planu badania, który powinien zawierać cel i zakres badania, listę członków uczestniczących, dane techniczne uwzględniające podział na części i elementy oraz wykaz proponowanych do użycia słów kluczowych, ustalenia administracyjne, harmonogramy spotkań wraz z datami, godzinami i lokalizacjami.

Badanie powinno przebiegać zgodnie z przyjętym planem. Zaleca się, aby na początku spotkania badawczego kierownik badania naszkicował plan badania, przedstawił plan projektu i wyjaśnił proponowane elementy oraz słowa kluczowe. Możliwe są dwie kolejności badania: „,najpierw element” albo „najpierw słowo kluczowe”.

W przemyśle chemicznym badanie rozpoczyna się od podziału instalacji na węzły badawcze. Pierwszy węzeł stanowi zazwyczaj pierwsza operacja procesowa lub aparat procesowy. W dalszej kolejności zespół analityczny dokonuje wyboru pierwszego odpowiedniego słowa kluczowego (dotyczącego potencjalnie możliwego do wystąpienia odchylenia). Następnie rozpoczyna się analiza poprzez ustalanie przyczyn występowania rozpatrywanego odchylenia. Pod uwagę brane są równocześnie spodziewane skutki wynikające z tego odchylenia i wreszcie projektowane są systemy bezpieczeństwa oraz ochrony (zabezpieczeń).

Dokumentacja w badaniu HAZOP odgrywa bardzo istotną rolę ze względu na to, że podstawową siłą HAZOP jest podejście systematyczne, zdyscyplinowane i udokumentowane. Kierownik badania jest odpowiedzialny za zapewnienie wykonania odpowiednich zapisów z każdego spotkania. Funkcjonują dwa rodzaje zapisywania HAZOP: pełny i poprzez wyjątki. Zapisywanie pełne polega na dokumentowaniu wszystkich wyników zastosowania każdej kombinacji słowo kluczowe-element/właściwość każdej części lub elementu planu projektu. Takie rozwiązanie, pomimo skomplikowania, zapewnia dowody, że badanie było szczegółowe i jest zalecane. 
Tabela 5. Przykład arkusza roboczego analizy HAZOP

\begin{tabular}{|c|c|c|c|c|c|c|}
\hline \multirow[b]{2}{*}{ NR } & \multirow{2}{*}{$\begin{array}{l}\text { Instalacja } \\
\text { Parametr }\end{array}$} & \multirow{2}{*}{$\begin{array}{c}\text { Węzeł } \\
\begin{array}{c}\text { Odchyle- } \\
\text { nie }\end{array}\end{array}$} & \multicolumn{4}{|c|}{ Arkusz HAZOP } \\
\hline & & & $\begin{array}{l}\text { Przy- } \\
\text { czyny }\end{array}$ & Skutki & Zabezpieczenia & Akcja \\
\hline \multirow{4}{*}{1} & \multirow{4}{*}{$\begin{array}{c}\text { Tempera- } \\
\text {-tura }\end{array}$} & \multirow{4}{*}{$\begin{array}{l}\text { Tempe- } \\
\text { ratura } \\
\text { wyższa } \\
\text { niż } 40 \\
\text { st. C }\end{array}$} & \multirow{4}{*}{$\begin{array}{c}\text { Uszko- } \\
\text {-dzenie } \\
\text { zaworu } \\
\text { ręczne- } \\
\text { go na } \\
\text { parze } \\
0,15 \\
\mathrm{MPa}\end{array}$} & \multirow{4}{*}{$\begin{array}{c}\text { Osiągnię- } \\
\text { cie tem- } \\
\text { peratury } \\
\text { maksy- } \\
\text { malnej } \\
\text { dla pary } \\
0,15 \mathrm{MPa} \\
\text { w zbior- } \\
\text { niku nie } \\
\text { przekra- } \\
\text { czające } \\
\text { jego pa- } \\
\text { rametrów } \\
\text { oblicze- } \\
\text { niowych }\end{array}$} & $\begin{array}{c}\text { Wahadło oparo- } \\
\text { we - wyrównanie } \\
\text { ciśnień ze zbiorni- } \\
\text { kiem magazyno- } \\
\text { wym }\end{array}$ & \multirow{4}{*}{$\begin{array}{c}\text { Wpro- } \\
\text { wadzić } \\
\text { sygnaliza- } \\
\text { cję prze- } \\
\text { kroczenia } \\
\text { tempera- } \\
\text { tury gra- } \\
\text { nicznej na } \\
\text { układzie } \\
\text { oparowym }\end{array}$} \\
\hline & & & & & $\begin{array}{c}\text { Zawory oddecho- } \\
\text { we na zbiorniku } \\
\text { C-1, C-2 }\end{array}$ & \\
\hline & & & & & $\begin{array}{l}\text { Instrukcje stano- } \\
\text { wiskowe, stały } \\
\text { nadzór w trakcie } \\
\text { rozładunku }\end{array}$ & \\
\hline & & & & & $\begin{array}{c}\text { Techniczne para- } \\
\text { metry obliczenio- } \\
\text { we wytrzymałości } \\
\text { zbiornika }\end{array}$ & \\
\hline
\end{tabular}

Źródło: opracowanie własne na podstawie autentycznych analiz HAZOP.

Zapisywanie wyjątków polega na dokumentowaniu tylko zidentyfikowanych zagrożeń i problemów zdolności do działania wraz z działaniami sprawdzającymi. Takie rozwiązanie ułatwia zarządzanie dokumentacją, ale jest mniej użyteczne dla auditu. Zaleca się, by wyniki badania HAZOP zawierały szczegóły dotyczące zidentyfikowanych zagrożeń i problemów, zalecenia dotyczące wszelkich dalszych badań, działania wymagane w celu uwzględnienia niepewności odkrytych podczas badania i zalecenia co do sposobów złagodzenia zidentyfikowanych problemów.

Zapisów wykonanej analizy HAZOP dokonuje się w charakterystycznym dla niej arkuszu roboczym (tabela 5).

Dalsze działania i odpowiedzialność związane są z tym, że kierownik badania rzadko jest uprawniony do zapewnienia, iż zalecenia zespołu badawczego zostaną wdrożone. Zaleca się, aby przed wprowadzeniem znaczących zmian z wyników badań HAZOP i gdy jest dostępna poprawiona dokumentacja, kierownik przedsięwzięcia rozważył powtórne spotkanie zespołu HAZOP, w celu zapewnienia, że nie zostały wprowadzone nowe 
zagrożenia lub problemy związane ze zdolnością do działania lub obsługowe.

Raport końcowy $\mathrm{z}$ analizy HAZOP powinien zawierać:

- temat i zakres analizy,

- skład zespołu analitycznego,

- wykaz dokumentów będących podstawą wykonania analizy,

- arkusze robocze,

- listę zdarzeń RZA (reprezentatywnych zdarzeń awaryjnych),

- wnioski dotyczące poziomu ryzyka,

- wnioski dotyczące listy dodatkowych zaleceń (zabezpieczeń) technicznych i organizacyjnych.

\section{PODSUMOWANIE}

Po przeanalizowaniu wszystkich wybranych węzłów badawczych dokonywana jest analiza wyników. Poszczególne zapisy w arkuszach dla każdego słowa kluczowego i węzła badawczego układają się w hipotetyczne sekwencje zdarzeń, które mogą być traktowane jako scenariusze awaryjne. $\mathrm{W}$ ten sposób powstaje lista zdarzeń awaryjnych, którą w toku dalszych pogłębionych analiz zawęża się do tzw. listy reprezentatywnych zdarzeń awaryjnych (RZA). Lista ta jest podstawą do opracowania scenariuszy awaryjnych [Górski, Jarzębowicz, 2002, s. 58].

Istotną korzyścią z badań HAZOP jest wynikająca z nich wiedza uzyskana przez identyfikowanie potencjalnych zagrożeń oraz problemów działania w sposób ustrukturyzowany i systematyczny, która stanowi wielką pomoc $\mathrm{w}$ formułowaniu właściwych środków zaradczych w zarządzaniu bezpieczeństwem procesowym. W tabeli 6 przedstawiono przykładową Macierz Ryzyka Procesowego wykorzystywaną w analizie HAZOP [Kosmowski, 2003, s. 107]. Poziom ryzyka szacowany jest na podstawie kombinacji częstości skutków (P) oraz kategorii skutków (S). 
Tabela 6. Przykład Matrycy Ryzyka Procesowego

\begin{tabular}{|c|c|c|c|c|c|c|}
\hline \multicolumn{2}{|c|}{ Kategoria skutków (S) } & pomijalne & małe & średnie & duże & katastrofa \\
\hline $\begin{array}{c}\text { Częstość skut- } \\
\text { ków 1/rok (P) }\end{array}$ & $\begin{array}{c}\text { Ozna- } \\
\text {-czenie } \\
\text { nume- } \\
\text {-ryczne }\end{array}$ & $\mathbf{1}$ & $\mathbf{2}$ & $\mathbf{3}$ & $\mathbf{4}$ & $\mathbf{5}$ \\
\hline $\begin{array}{c}10^{0}-10^{1} \text { bardzo } \\
\text { częste }\end{array}$ & 1 & TNA & TNA & NA & NA & NA \\
\hline $10^{-1}-10^{-2}$ częste & 2 & TA & TNA & TNA & NA & NA \\
\hline $\begin{array}{c}10^{-2}-10^{-3} \\
\text { możliwe }\end{array}$ & 3 & TA & TA & TNA & TNA & NA \\
\hline $\begin{array}{c}10^{-3}-10^{-4} \\
\text { sporadyczne }\end{array}$ & 4 & A & TA & TA & TNA & TNA \\
\hline $\begin{array}{c}10^{-4}-10^{-5} \\
\text { rzadkie }\end{array}$ & 5 & A & A & TA & TA & TNA \\
\hline $\begin{array}{c}10^{-5}-10^{-6} \\
\text { bardzo rzadkie }\end{array}$ & 6 & A & A & A & TA & TA \\
\hline $\begin{array}{c}10^{-6}-10^{-7} \text { prawie } \\
\text { niemożliwe }\end{array}$ & 7 & A & A & A & A & TA \\
\hline
\end{tabular}

Źródło: opracowanie własne na podstawie autentycznych analiz HAZOP.

W tabeli 7 zestawiono kategorie skutków w czterech obszarach: pracownicy, ludność, środowisko i majątek.

Tabela 7. Przykład kategoryzacji skutków

\begin{tabular}{|c|c|c|c|c|}
\hline Kategorie & Pracownicy & Ludność & Środowisko & Majątek \\
\hline Kat.1 & $\begin{array}{c}\text { Bardzo drobne } \\
\text { urazy }\end{array}$ & Brak & Brak & Minimalne \\
\hline Kat.2 & $\begin{array}{c}\text { Pojedyncze } \\
\text { urazy }\end{array}$ & Odór, hałas & $\begin{array}{c}\text { Małe } \\
\text { odnotowane } \\
\text { w raportach }\end{array}$ & Do 100.000,- zł \\
\hline Kat. 3 & $\begin{array}{c}\text { Średnie urazy, } \\
\text { pojedyncze } \\
\text { ciężkie urazy }\end{array}$ & Małe urazy & $\begin{array}{c}\text { Średnie } \\
\text { zniszczenia }\end{array}$ & Do 1.000.000,- zł \\
\hline
\end{tabular}


Cd. tab. 7

\begin{tabular}{|c|c|c|c|c|}
\hline Kategorie & Pracownicy & Ludność & Środowisko & Majątek \\
\hline Kat. 4 & $\begin{array}{c}\text { Liczne ciężkie } \\
\text { urazy }\end{array}$ & Średnie urazy & $\begin{array}{c}\text { Poważne } \\
\text { zniszczenia }\end{array}$ & Do 8.000.000,- zł \\
\hline Kat. 5 & $\begin{array}{c}\text { Ofiary śmier- } \\
\text { telne }\end{array}$ & Ciężkie urazy & $\begin{array}{c}\text { Katastrofa } \\
\text { ekologiczna }\end{array}$ & $>8.000 .000,-$ zł \\
\hline
\end{tabular}

Źródło: opracowanie własne na podstawie autentycznych analiz HAZOP.

W celu zwiększenia bezpieczeństwa procesowego dla tych zagrożeń, dla których poziom ryzyka został oceniony na poziomie TNA i NA oraz dla TA ustala się propozycje dodatkowych zabezpieczeń technicznych i organizacyjnych oraz dokonuje oceny możliwości realizacyjnych. Zapisy z analizy dokonywane są w specjalnym arkuszu (tabela 8).

Tabela 8. Wzór listy dodatkowych zabezpieczeń

\begin{tabular}{|l|c|c|c|c|c|c|}
\hline \multirow{2}{*}{ Nr RZA } & \multirow{2}{*}{$\begin{array}{c}\text { Opis dodatko- } \\
\text { wych zaleceń }\end{array}$} & \multicolumn{2}{|c|}{$\begin{array}{c}\text { Ocena wpływu zabezpie- } \\
\text { czeń na poziom P, S i R }\end{array}$} & \multirow{2}{*}{$\begin{array}{c}\text { Odpowiedzialny } \\
\text { za realizację }\end{array}$} & \multirow{2}{*}{ Termin } \\
\cline { 4 - 5 } & & $\mathbf{P}$ & $\mathbf{S}$ & $\mathbf{R}$ & & \\
\hline & & & & & & \\
\hline
\end{tabular}

Źródło: opracowanie własne na podstawie autentycznych analiz HAZOP.

Oczekuje się, że wprowadzenie dodatkowych zabezpieczeń pozwoli na zmniejszenie poziomu ryzyka z TNA lub NA do TA lub A, co w konsekwencji prowadzi do wzrostu bezpieczeństwa procesowego.

\section{LITERATURA}

Borysiewicz M., Furtek A., Potempski S. (2000), Poradnik metod ocen ryzyka zwiazanego z niebezpiecznymi instalacjami procesowymi, Instytut Energii Atomowej, Otwock - Świerk.

Górski J., Jarzębowicz A. (2002), Wykrywanie anomalii w modelach obiektowych za pomoca UML-HAZOP, Materiały IV KOnferencji Inżynierii Oprogramowania, Poznań. 
Gruhn P., Chedde H. L. (2006), Safety Instrument Systems: Design, Analysis and Justification, 2nd Ed, Research Triangle Park, ISA.

Kletz T. (1999), HAZOP and HAZAN, Taylor \&Francis, Oxford.

Kosmowski, K. T. (2003), Metodyka analizy ryzyka w zarządzaniu niezawodnościa i bezpieczeństwem elektrowni jądrowych, Wydawnictwo PG, Gdańsk.

Kunicki T., Matus B., Zabielski A. (2001), Nowoczesne tendencje $w$ dziedzinie zapewnienia bezpieczeństwa na instalacjach chemicznych, „Nowoczesne Gazownictwo", nr 2.

PN-IEC 61882, 2005, Badania zagrożeń i zdolności do działania (badania HAZOP) - Przewodnik zastosowań.

Redmill F., Chudleigh M., Catmur J. (1999), System safety: HAZOP and Software HAZOP, John Wiley\&Sons, New York.

\title{
HAZOP AS A SUPPORTING METHOD OF THE ENTERPRISE PROCESS SAFETY MANAGMENT
}

\begin{abstract}
The article is an attempt to show the HAZOP method role in the enterprise process safety management. HAZOP method is hazard and operability analysis used for process risk assessment described in details according to IEC 61882 "Hazard and operability studies (HAZOP studies) - Application guide" published in 2001. The goal of the HAZOP analysis is to identify all potential risks and losses that may occur during ongoing activities. It has a great importance in the process safety management especially in the chemical, petrochemical, gas and energy industries.
\end{abstract}

Keywords: management; process management; operational risk management. 